\section{Dean of the Faculty of Medicine at Birmingham}

Dr. A. Stanley Barnes has resigned his post as dean of the Faculty of Medicine in the University of Birmingham after ten years in office. Dr. Barnes, who was a student of Mason College, in addition to being closely associated with the local hospitals, attained an outstanding position as a consultant. About ten years ago he sacrificed his professional practice to become dean of the Faculty of Medicine, in which office he assisted in the planning and building of the City Hospitals Centre and the new Medical School of the University. He was a liberal donor to the building funds of the Medical School, and the perfection of the building and equipment reflects in many directions both his discriminating generosity and constant supervisory care. The Council of the University has recorded its grateful recognition of the valuable and devoted service which he has rendered to the University and to the cause of medical education in Birmingham generally.

Dr. Barnes is succeeded as dean by Dr. Leonard Gregory Parsons, professor of infant hygiene and diseases of children, who has been acting as deputy dean. Dr. Parsons, who was educated at King Edward's School, Aston, and the University of Birmingham, is physician to the United and Children's Hospitals, and was chairman of the Children's Hospital, an office which he resigned in January last, to become Midland Regional Hospital Officer to the Ministry of Health. During 1916-18, serving in the R.A.M.C., Dr. Parsons was officer in charge of the Medical Division 36th General Hospital, British Salonika Force, the Order of St. Sava of Serbia being conferred on him in 1917. He was vice-president of the International Congress of Prdiatrics at Stockholm in 1930 and president of the Children's Section of the Royal Society of Medicine during 1932--33.

\section{Science and World Order}

SPEAKING at a meeting convened by the Faculty of Science of Marx House on October 5, Prof. J. D. Bernal summed up the Conference on Science and World Order. The meeting, he said, tended to avoid reference to the difficulties of scientific planning at the present time. The first necessity is to win the War, and the time for planning is now. It is simple to see what we need from science, namely, an environment in which material things are at their best and have the ability to obtain a secure social life. Want and war are the two chief horrors of to-day. Science has pointed the way to remove them and will $r \in$ move them if the peoples of the world co-operate with the scientific workers.

The attitude of complacency which existed in the higher scientific world is broken. Dissatisfaction is not confined to younger men of science but has reached the senior men. Dr. J. P. Lawrie, speaking at the same meeting, directed attention to the opposition displayed by high political personages when Prof. A. V. Hill organized a liaison between the men of science of Great Britain, the United States and Canada. $\mathrm{He}$ is of opinion that any plans made by men of science must secure the backing of the people before they can be put into effect by any Government. This means that men of science must thoroughly instruct the people, and this can best be done through the daily Press.

\section{A Scientific Press Bureau}

Mr. D. S. Evans, University Observatory, Oxford, writing with reference to the letter in NATURE of September 27 by Mr. D. L. Johnston urging the need for a scientific press bureau, states that the Association of Scientific Workers has devoted considerable attention to this problem. A scheme has been drafted by the Association whereby each of its more than fifty branches all over Great Britain can act as centres of diffusion for simple and accurate facts on scientific problems of current importance, and it is hoped that this organization will begin functioning in a few weeks. It is an amateur organization, but its possibilities are considerable, and experience will be gained which will be invaluable if, and when, a more formal body is set up. Mr. Evans states that the Association intends to develop this propaganda work for science by every means in its power, and co-operation with other organizations or individuals will be heartily welcomed.

Point is given to the proposal by headlines which appeared in a recent issue of a well-known London evening newspaper. The headlines read "Anti-Gas Serum is Being Sent To Russia" ; the accompanying letter-press indicates that the reference is actually to gas-gangrene serum. The mistake is understandable, but nevertheless emphasizes the need for scientific guidance.

\section{Dr. Arthur Gamgee (184I-I909)}

Dr. Arthur Gamger, F.R.S., physiologist and consulting physician, was born at Florence on Oetober 10, 1841 , the son of a veterinary surgeon and pathologist. From the outset of his career he showed a special interest in physiology, particularly physiological chemistry, as was evidenced by his inaugural thesis at Edinburgh entitled "Contributions to the Chem. istry and Physiology of Fœtal Nutrition". From 1863 until 1869 he was assistant to Dr. Maclagan, professor of medicine at Edinburgh, during which time he published several papers showing his outstanding ability to deal with abstruse physiological problems. In 1873 he was appointed the first Brackenbury pro. fessor of physiology at Owens College, now the University of Manchester. During the thirteen years he was there he took an active part in the work of the medical school, of which he was dean, and wrote numerous articles on physiology and pharmacology. He was also Fullerian professor of physiology at the Royal Institution during 1882-85, when he left Manchester. Eventually he moved to Cambridge, where he devoted himself to scientific research. Finally, he decided to live abroad and settled first at Lausanne and afterwards at Montreux.

Gamgee's chief publications were "A Text-book of the Physiological Chemistry of the Animal Body, including an Account of the Chemical Changes Occurring in Disease" (1880-1893) and "Physiology of Digestion" 